\title{
KOMUNIKATY
}

Stanisław Siess-Krzyszkowski

Centrum Badawcze Bibliografii Polskiej Estreicherów,

Uniwersytet Jagielloński, Kraków, Polska

stan.siess@uj.edu.pl

ORCID 0000-0002-4309-4268

\section{Psałterz Dawidow w przekładzie Mikołaja Reja. Nowe ustalenia chronologii wydań i impresorów}

W żadnym ze znanych w literaturze przedmiotu egzemplarzy dwu wydań (A i B $)^{1}$ „Psałterza Dawidowego” w thumaczeniu Mikołaja Reja nie zachował się kolofon. W przypadku wyd. B nie zachował się też egzemplarz z kartą tytułową. Z chwilą odnalezienia w Bibliotece Uniwersyteckiej w Erlangen kompletnego egzemplarza wydania A (sygn. H00/THL-II 39) sprawa roku jego druku zostaje zamknięta ${ }^{2}$. W kolofonie czytamy: „W krakowie przez Maćieia Szarffenberka. Lata bożego. 1543. Dnia dziesiątego Kxiężyca Maia” (fot. 1). Jak wpasować tę datę w ewolucję przekonań religijnych Reja - to pytanie do znawców jego twórczości.

W egzemplarzu z Erlangen ważna jest jeszcze karta $A_{\text {iv }}$ - na jej recto znajdujemy dokończenie wiersza Ku temu: co by miat wola czysć kxiąszki, na verso - drzeworyt przedstawiający króla Dawida śpiewającego psalmy (fot. 2). Drzeworyt ten znany jest też z Żołtarza Dawidowego Walentego Wróbla wydanego w Krakowie w 1543 r. u Macieja Szarfenberga (egzemplarz w Ossoli-

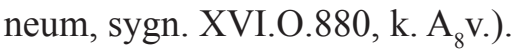

T.Witczak, Studia nad twórczościa Mikołaja Reja, Warszawa-Poznań 1975, s. 55-59.

2 KVK - KarlsruherVirtuellerKatalog [online], https://nbn-resolving.org/urn:nbn:de:bvb:29-bv022195999-9 [dostęp 04.11.2019].

„Z Badań nad Książką i Księgozbiorami Historycznymi” - Udział zagranicznych recenzentów w ocenie publikacji; Stworzenie anglojęzycznej wersji wydawniczej publikacji; Digitalizacja tomów archiwalnych rocznika w celu zapewnienia otwartego dostępu do nich przez Internet oraz wdrożenie i utrzymanie cyfrowej platformy redakcyjnej - zadanie finansowane w ramach umowy $\mathrm{nr}$ 653/P-DUN/2019 ze środków Ministra Nauki i Szkolnictwa Wyższego przeznaczonych na działalność upowszechniającą naukę. 
Pozostaje więc do ustalenia rok druku i impresor wydania B. W Katalogu druków XVI wieku w zbiorach Biblioteki Uniwersyteckiej w Warszawie podano miejsce wydania: Kraków, rok wydania: przed $1550^{3}$. Rzecz w tym, że zachowany fragment dedykacji do wydania $\mathrm{B}$ jest dosłownym przedrukiem z wydania 1543 r., czyli albo trzeba założyć, że zmieniono jej adresata z Zygmunta I na Zygmunta Augusta, co jest mało prawdopodobne, albo raczej przyjąć, że wydanie B ukazało się jeszcze za życia Zygmunta I, czyli przed kwietniem 1548. Pewną wskazówką może być grafia wydania B - jedyna istotna różnica w stosunku do wydania A (r. 1543). W szczególności dotyczy to sposobu zapisywania zmiękczenia spółgłosek przed samogłoską. W drukach M. Szarfenberga z początku lat 40. dominuje zapis zmiękczenia za pomocą „i”, pod koniec dziesięciolecia - za pomocą „y”4. Oto przykłady z dwu wydań Szarfenberga Żottarza Wróbla:

1. Argument do psalmu 141 z edycji 1543 r. (k. Ss $s_{1}$.): „Wtym pieniu prorok prorokuie iako się pan Jesus miał modlić oycu, iako go żydowie mieli podchwytać, $[\ldots] "$.

2. Argument do psalmu $141 \mathrm{z}$ edycji 1547 r. (k. 333v.-334r.): „W tym pyenyu prorok prorokuye yako sye pan Jezus myał modlić Bogu oycu. Iako go żydowye myeli podchwytać. [...]."

I argument do tegoż psalmu w wydaniach A i B Psatterza Reja (tu Psalm $142)^{5}$ :

1. Wydanie A (k. 209v.): „Człek sprawiedliwy będąc w udręczeniu woła o ratunek do pana swego powiedaiąc iż niskąd inąd go upatrzyć nie może [...]."

2. Wydanie B (k. 218v.): „Człek sprawyedliwy będąc w udręczenyu woła o ratunek do Pana swego, powyedayąc iż niskąd inąd go upatrzyć nye może [...]."

Ponieważ analiza typograficzna wydania B jednoznacznie wskazuje na oficynę M. Szarfenberga (zm. przed 24 V 1547) - można przypuścić, że wydanie to ukazało się pod jego firmą w przed majem 1547 r. lub między czerwcem tegoż roku a marcem roku następnego pod firmą Hieronima, syna Macieja.

3 T. 2, cz. 1, Warszawa 1998, poz. 1550.

4 Zmiękczanie za pomocą „y” jest też charakterystyczne dla druków Hieronima Szarfenberga (np. Kronika Wssytkygo swyata Marcina Bielskiego wydana w 1554 r.).

5 Numeracja Biblii hebrajskiej. 
Fot. 1. Kolofon Psałterza Dawidowego w przekładzie Mikołaja Reja (wyd. A, k. Ff iii ir). Źródło: Universitäsbibliothek Erlangen-Nürnberg

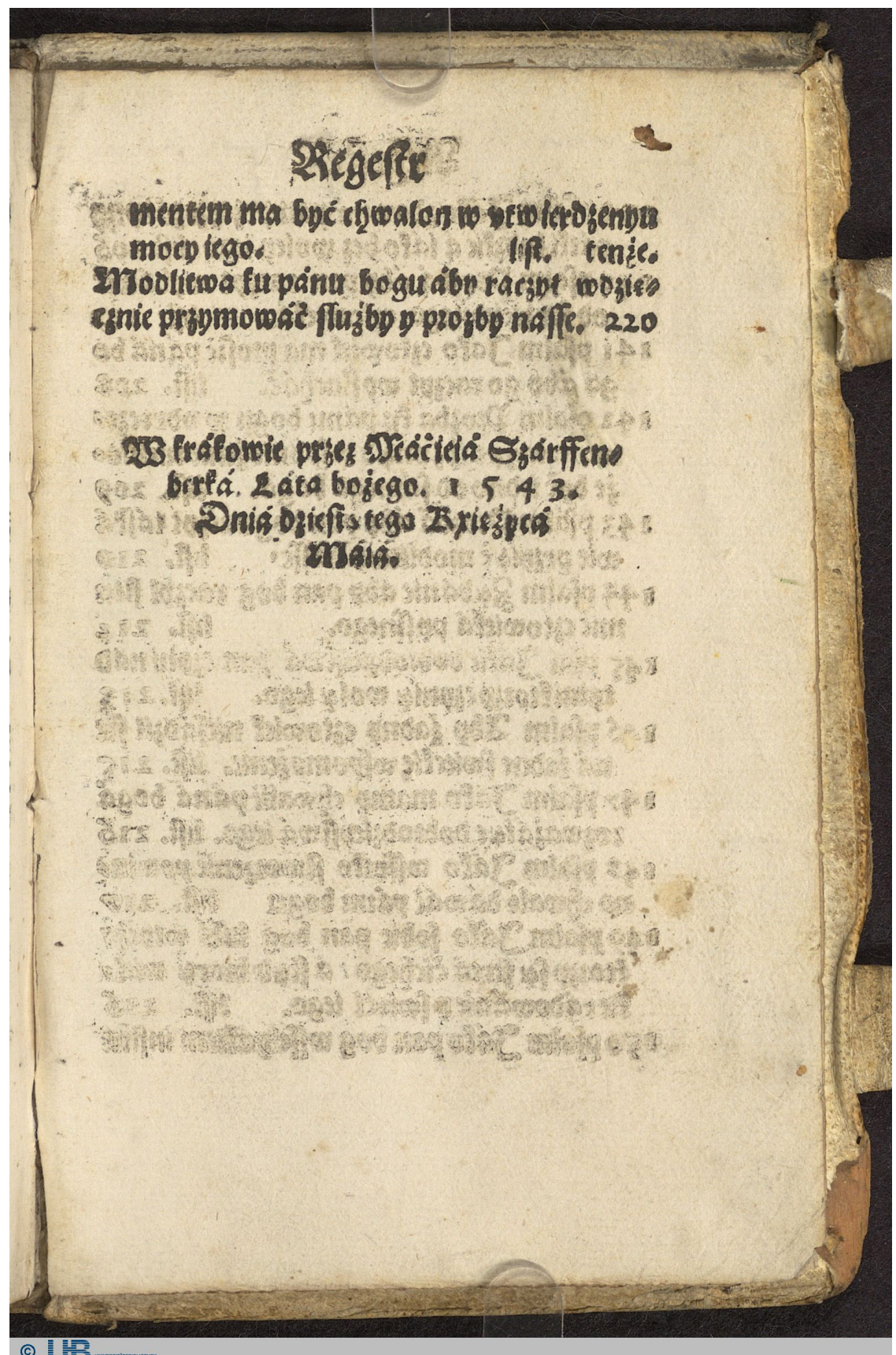


Fot. 2. Drzeworyt: król Dawid śpiewający Psalmy (Psatterz Dawidow, wyd. A, k. $\left.A_{i v} v\right)$, autor anonimowy. Źródło: Universitäsbibliothek Erlangen-Nürnberg

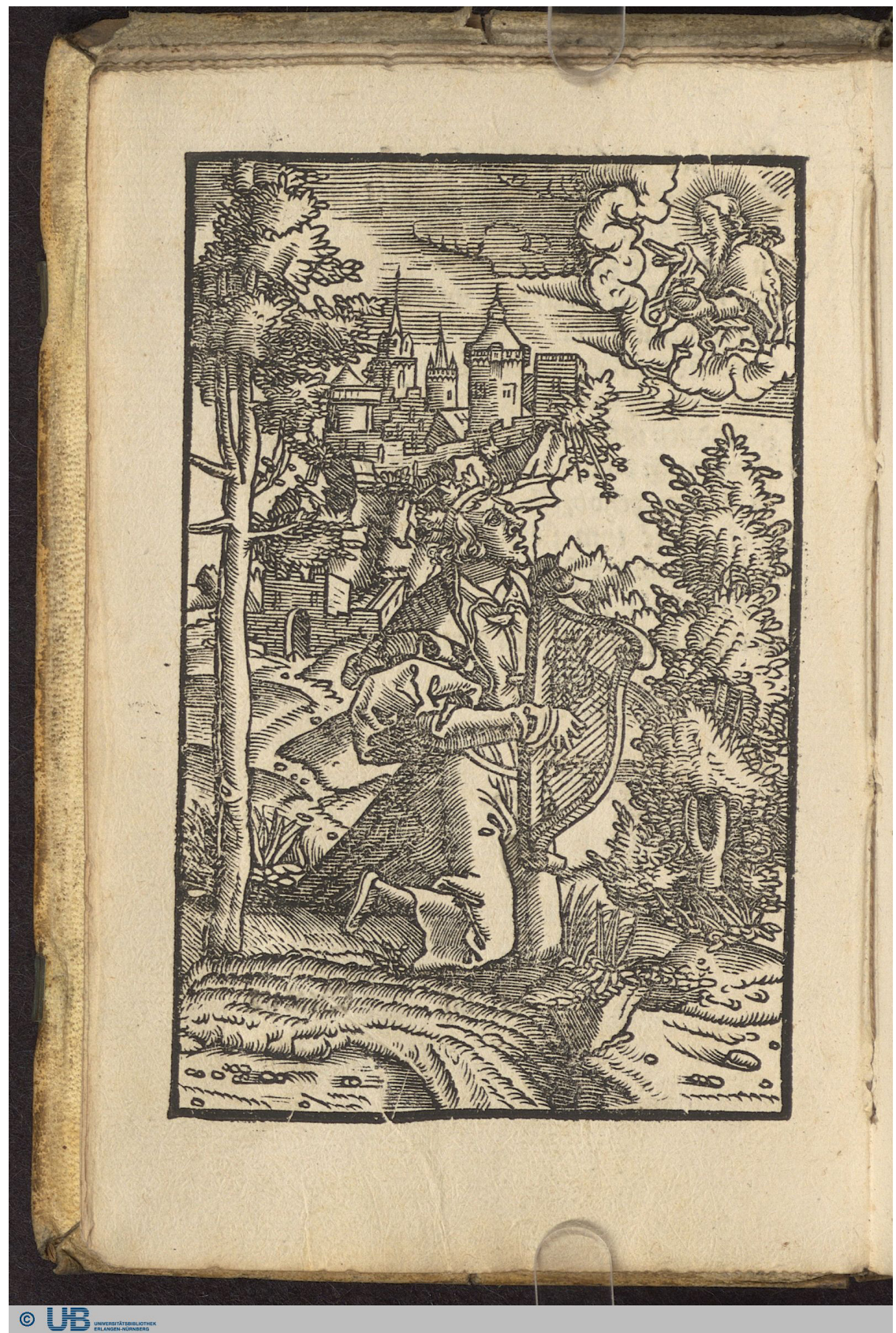

